\title{
Correction to: Microabrasion effect on enamel susceptibility to penetration of hydrogen peroxide: an experimental and computational study
}

Daiane Costa ${ }^{1}$ - Agnes Meireles ${ }^{1,2}$. Janaína Luciana Ferreira ${ }^{1,2}$. Polyana Alcântara ${ }^{1} \cdot$ Libardo Andrés Torres $^{1}$. João Victor Frazão Câmara ${ }^{1,3}\left[\right.$. . Josué Junior Pierote ${ }^{1,4} \cdot$ Marcus Henrique Canuto $^{1}$. Cintia Tereza Araújo ${ }^{1}$

Published online: 8 April 2021

(c) The Society of The Nippon Dental University 2021

\section{Correction to: Odontology \\ https://doi.org/10.1007/s10266-021-00598-0}

In the original publication of the article, Eq. 1 was published incorrectly. The correct Eq. 1 is provided below,

$\frac{\partial c}{\partial t}=D \frac{\partial^{2} c}{\partial x^{2}}-k c$

Publisher's Note Springer Nature remains neutral with regard to jurisdictional claims in published maps and institutional affiliations.

The original article can be found online at https://doi.org/10.1007/ s10266-021-00598-0.

João Victor Frazão Câmara jvfrazao92@hotmail.com

1 Universidade Federal dos Vales do Jequitinhonha e Mucuri, Diamantina, Brazil

2 Universidade Federal de Minas Gerais, Belo Horizonte, Brazil

3 Universidade de São Paulo, Faculdade de Odontologia de Bauru, Bauru, Brazil

4 Universidade Estadual de Campinas, Faculdade de Odontologia de Piracicaba, Piracicaba, Brazil 